\title{
Seed Quality of Okra Produced after Bio-Priming
}

\author{
Anuj Kumar Rai ${ }^{1 *}$, Himangshu Das ${ }^{2}$ and Asit Kumar Basu ${ }^{3}$ \\ ${ }^{1}$ Krishi Vigyan Kendra, Malkangiri, OUAT, Odisha-764045, India \\ ${ }^{2}$ RRTTSS, Kalimela, Malkangiri, OUAT, Odisha-764045, India \\ ${ }^{3}$ Bidhan Chandra Krishi Viswavidyalaya, Mohanpur, West Bengal, Nadia -741252, India \\ *Corresponding author
}

\section{A B S T R A C T}

\section{Keywords}

Okra, Germination

(\%), Protein

content,

Trichoderma viride,

Pseudomonas

fluorescence

Article Info

Accepted:

17 May 2019

Available Online:

10 June 2019
Okra seeds produced after pre-sowing bio-priming with Trichoderma viride and Pseudomonas fluorescencewere subjected to laboratory testing at Directorate of Research, Bidhan Chandra Krishi Viswavidyalaya, Kalyani, Nadia, West Bengalfor its quality assessment through germination, seedling length, vigour index, protein content and carbohydrate content. Significant differences among the varieties as well as treatments were observed for all the parameters studied, but variety $\mathrm{x}$ bio-priming interaction was insignificant for germination $(\%)$ and carbohydrate content. Seeds bio-primed with Trichoderma viride for var. Japani Jhar (86.83\%), Ramya (19.7cm) and Arka Anamika, (1544.4) significantly enhance the germination (\%), seedling length and vigour index respectively, whereas protein and carbohydrate was observed more in Arka Anamika and Ramya with same treatment. Greater influence of Trichoderma viride for enhanced all quality parameters could be recognized in comparison to that of Pseudomonas fluorescens and control.

\section{Introduction}

Okra (Abelmoschus esculentus L. Moench) is one of the main vegetable crops of India and having global leader in production (Saxena et al., 2016). Okra has a prominent position among vegetable fruits due to its high nutritive and medicinal value, ease of cultivation, and wider adaptability to varying weathers (Reddy et al., 2012 and Meena et al., 2017). Seed is the most valuable and important input among all essentials in crop production. The old says "Seed is the beginning of Life" and a good quality seed acts as a catalyst for realizing the potential of all other inputs in agriculture. Without good seed, the investment on fertilizer, water, pesticides and other inputs cannot pay the desired dividends. Therefore, production of quality seed as well as its maintenance with high germination potential and vigour status is of utmost importance in a seed programme. Seed treatment with the bio- agents is the most effective tools to protect from seed and soil born diseases in early stage of development of crop (Singh et al., 2013; Jain et al., 2013) as well as reduce the dependability on chemical treatment for 
disease management (Challan et al., 1997; Pill et al., 2009). Trichoderma spp. is one of the most common free-living saprophytic fungi in rhizosphere which widely occupy the major share of fungal biocontrol agents in biopesticide industry (Woo et al., 2014). Trichoderma spp. not only promotes plant growth and development but also have broadspectrum antagonistic activities against various soil borne. At the initial stage, Trichoderma spp. were worked extensively for disease management and yield enhancement (Harman, 2006), even under adverse conditions also (Lo et al., 2000 and Yedidia et al., 2001). This has evolved multiple mechanisms resulting in improvement in plant growth and resistance to diseases as well as in productivity (Harman et al., 2004 and Vinale et al., 2008 Enhanced growth response induced by Trichoderma sp. has been reported for many crops such as beans, cucumber, pepper (Lo and Lin, 2002). Pseudomonas species are also effective root colonizers and bio-control agents, through production of antibiotics and other antifungal metabolites (O'Sullivan and O'Gara, 1992). Enhancement in both dry weight and plant height was recorded after application of Pseudomonas sp. MML2212 and Pseudomonas fluorescens on rice and green gram in comparison to that of control (Mathivanan et al., 2005; Shanmugaiah et al., 2005 \& 2007). Pseudomonas fluorescens improved germination parameters (Moeinzadeh et al., 2010) and for control of Alternaria blight (Rao et al., 2009) in sunflower, Trichoderma harzianum for control of Fusarium verticillioides in maize (Nayaka et al., 2010). Keeping the above points, bio- priming considered as the most effective method of seed quality enhancement. The main objective of the present work is to evaluate the response of bio-priming with Trichoderma viride and Pseudomonas fluorescens on seed quality of okra.

\section{Materials and Methods}

The present experiment was carried out at Directorate of Research, Bidhan Chandra Krishi Viswavidyalaya, Kalyani, Nadia, West Bengal, in summer $2011 \& 2012$ to assess the quality of okra seeds produced after presowing bio-priming withTrichoderma viride and Pseudomonas fluorescence. Seeds of the varieties viz., Lalu, Arka Anamika, Ramya, Satsira, Lady Luck, Debpusa Jhar, Japani Jhar and Barsha Laxmi were first soaked for two hours in spore suspension of Trichoderma viride strain $\mathrm{TV}-4$ and conidia suspension of Pseudomonas fluorescence strain Psf- 2, and then shade drying was made.

Bio- primed seeds along with unprimed control were sown infield with three replications following Split- plot design and harvested at maturity stage. Seeds produced after pre-sowing bio-priming of seeds were subjected to laboratory testing for its quality assessment through germination, seedling length and vigour index, soluble protein and carbohydrate, and the pooled data shown in Table 1 and 2.

\section{Germination percentage}

Germination tests were carried out utilizing sterile building grade sand as substratum following ISTA (1985).

$$
\text { Germination } \%=\frac{\text { Number of normal seedlings produced }}{\text { Total number of seeds used }} \times 100
$$

\section{Seedling length $(\mathrm{cm})$}

For seedling length, twenty seeds for individual varieties were placed in moistened sand kept in plastic pots separately and ten normal seedlings were taken randomly on tenth day as seedlings were died beyond that day, and total seedling length was measured in centimeter. Average was made accordingly. 


\section{Vigour index}

For determination of vigour index, average seedling length was multiply by average germination percentage following Abdul-Baki and Anderson (1973) for each variety and replication.

Vigour index $=$ Germination $(\%) \times$ Average seedling length $(\mathrm{cm})$

\section{Total protein}

Estimation of total protein in seed of okra was done according to the method proposed by Lowry et al., 1951.

\section{Total carbohydrates}

Estimation of total carbohydrate of okra seed was estimated by anthron method as suggested by Hedge and Hofreiter, 1962.

Amount of carbohydrate present in $100 \mathrm{mg}$ of the sample

$$
=\frac{\mathrm{mg} \text { of glucose }}{\text { Volume of test sample }} \times 100
$$

\section{Results and Discussion}

Seeds produced after pre-sowing bio-priming of seeds were subjected to laboratory testing for its quality assessment through germination, seedling length, vigour index, protein and carbohydrate content. Significant differences among the varieties as well as treatments were observed for all the parameters studied, but variety $\mathrm{x}$ bio-priming interaction was insignificant for germination (\%) and carbohydrate content.

\section{Germination (\%)}

Significantly higher germination was recorded of Japani Jhar (84.22\%) followed by Satsira, Lalu, Arka Anamika and Barsha Laxmi (Table 1) whereas lowest was noted for Debpusa Jhar (68.61\%), when average was made over the treatments. After averaging over the varieties, it was noticed that highest magnitude of seed germination was recorded when bio-priming was made with Trichoderma viride followed by that with Pseudomonas fluorescens. Japani jhar $(86.83 \%)$ revealed the higher germination potential when priming with Trichoderma viride.

\section{Seedling length $(\mathrm{cm})$}

Ramya (19.03) and Arka Anamika (19.05 cm) were produced significantly longest seedlings, when overall performance of the individual varieties were considered followed by Japani Jhar, Debpusa Jhar, Barsha Laxmi and Lady Luck, while most dwarf type seedling produced by Satsira. Greater influence of Trichoderma viride was found over unprimed control as well as Pseudomonas fluorescens, when average was made over the varieties (Table 1).

Ramya (19.70cm) produced the longest seedling when treated with Trichoderma viride whereas Greater influence of Pseudomonas fluorescens over the Trichoderma viride was noted for Satsira $(15.48 \mathrm{~cm})$ but it was statically at par with Trichoderma viride.

\section{Vigour index}

Seedling vigour Index, being the complex character determined through joint function of germination percentage and average seedling length, expressed unique trend for performance of individual varieties. Critical analysis on average performance of individual varieties for this derived seedling parameter may lead to identify Arka Anamika and Japani Jhar as the superior most varieties for expression of this important character, followed by Ramya and Lalu. 
Table.1 Seed quality of okra produced after pre-sowing bio-priming

\begin{tabular}{|c|c|c|c|c|c|c|c|c|c|c|c|c|}
\hline \multirow[t]{2}{*}{$\begin{array}{c}\text { Varieties } \\
\text { (V) }\end{array}$} & \multicolumn{4}{|c|}{ Average germination (\%) } & \multicolumn{4}{|c|}{$\begin{array}{l}\text { Average length of seedlings } \\
\text { (cm) }\end{array}$} & \multicolumn{4}{|c|}{ Vigour Index- I } \\
\hline & $\mathbf{T}_{\mathbf{0}}$ & $\mathbf{T}_{1}$ & $\mathbf{T}_{2}$ & Mean & $\mathbf{T}_{\mathbf{0}}$ & $\mathbf{T}_{1}$ & $\mathbf{T}_{2}$ & Mean & $\mathbf{T}_{\mathbf{0}}$ & $\mathbf{T}_{1}$ & $\mathbf{T}_{2}$ & Mean \\
\hline Lalu & $\begin{array}{c}75.67 \\
(60.85)\end{array}$ & $\begin{array}{c}84.50 \\
(67.31)\end{array}$ & $\begin{array}{c}81.33 \\
(64.87)\end{array}$ & $\begin{array}{c}80.50 \\
(64.34)\end{array}$ & 15.30 & 16.51 & 16.43 & 16.08 & 1157.81 & 1394.59 & 1336.55 & 1296.32 \\
\hline $\begin{array}{c}\text { Arka } \\
\text { Anamika }\end{array}$ & $\begin{array}{c}73.33 \\
(59.27)\end{array}$ & $\begin{array}{c}79.17 \\
(63.35)\end{array}$ & $\begin{array}{c}76.83 \\
(61.66)\end{array}$ & $\begin{array}{c}76.44 \\
(61.43)\end{array}$ & 18.24 & 19.51 & 19.35 & 19.03 & 1337.52 & 1544.40 & 1487.00 & 1456.31 \\
\hline Ramya & $\begin{array}{c}67.50 \\
(55.60)\end{array}$ & $\begin{array}{c}74.17 \\
(59.88)\end{array}$ & $\begin{array}{c}71.33 \\
(58.09)\end{array}$ & $\begin{array}{c}71.00 \\
(57.86)\end{array}$ & 18.03 & 19.70 & 19.42 & 19.05 & 1216.57 & 1460.42 & 1385.16 & 1354.05 \\
\hline Satsira & $\begin{array}{c}79.83 \\
(63.78)\end{array}$ & $\begin{array}{c}84.83 \\
(67.60)\end{array}$ & $\begin{array}{c}83.83 \\
(66.82)\end{array}$ & $\begin{array}{c}82.83 \\
(66.07)\end{array}$ & 14.48 & 15.52 & 15.48 & 15.16 & 1155.94 & 1316.82 & 1297.58 & 1256.78 \\
\hline Lady Luck & $\begin{array}{c}69.33 \\
(56.72)\end{array}$ & $\begin{array}{c}77.67 \\
(62.20)\end{array}$ & $\begin{array}{c}71.17 \\
(57.88)\end{array}$ & $\begin{array}{c}72.72 \\
(58.93)\end{array}$ & 15.15 & 17.04 & 16.97 & 16.39 & 1049.99 & 1322.87 & 1207.47 & 1193.45 \\
\hline $\begin{array}{c}\text { Debpusa } \\
\text { Jhar }\end{array}$ & $\begin{array}{c}66.00 \\
(54.67)\end{array}$ & $\begin{array}{c}71.17 \\
(57.90)\end{array}$ & $\begin{array}{c}68.67 \\
(56.30)\end{array}$ & $\begin{array}{c}68.61 \\
(56.29)\end{array}$ & 17.06 & 18.11 & 18.03 & 17.73 & 1125.43 & 1288.67 & 1237.61 & 1217.24 \\
\hline $\begin{array}{c}\text { Japani } \\
\text { Jhar }\end{array}$ & $\begin{array}{c}81.67 \\
(65.14)\end{array}$ & $\begin{array}{c}86.83 \\
(69.28)\end{array}$ & $\begin{array}{c}84.17 \\
(67.23)\end{array}$ & $\begin{array}{c}84.22 \\
(67.22)\end{array}$ & 16.59 & 17.58 & 17.58 & 17.25 & 1355.42 & 1527.20 & 1480.37 & 1454.33 \\
\hline $\begin{array}{l}\text { Barsha } \\
\text { Laxmi }\end{array}$ & $\begin{array}{c}68.17 \\
(55.99)\end{array}$ & $\begin{array}{c}75.83 \\
(60.97)\end{array}$ & $\begin{array}{c}74.67 \\
(60.15)\end{array}$ & $\begin{array}{c}72.89 \\
(59.04)\end{array}$ & 16.79 & 17.73 & 17.69 & 17.40 & 1144.51 & 1343.89 & 1321.11 & 1269.84 \\
\hline Mean & $\begin{array}{c}72.69 \\
(59.00)\end{array}$ & $\begin{array}{c}79.27 \\
(63.56)\end{array}$ & $\begin{array}{c}76.50 \\
(61.62)\end{array}$ & & 16.45 & 17.71 & 17.62 & & 1192.90 & 1399.86 & 1344.11 & \\
\hline & $\mathbf{V}$ & $\mathbf{T}$ & VXT & & $\mathbf{V}$ & $\mathbf{T}$ & VXT & & $\mathbf{V}$ & $\mathbf{T}$ & & \\
\hline $\operatorname{SEm}( \pm)$ & 0.71 & 0.44 & 1.23 & & 0.04 & 0.03 & 0.08 & & 17.71 & 10.84 & & \\
\hline CD at $5 \%$ & 2.00 & 1.23 & NS & & 0.12 & 0.08 & 0.21 & & 49.73 & 30.45 & & \\
\hline CD at $1 \%$ & 7.44 & 4.55 & NS & & 0.46 & 0.28 & 0.80 & & 184.90 & 113.23 & & 25 \\
\hline
\end{tabular}

$\mathrm{T}_{0^{-}}$Control, $\mathrm{T}_{1^{-}}$Trichoderma viride, $\mathrm{T}_{2^{-}}$Pseudomonas fluorescens 
Table.2 Biochemical changes of okra seed produced after pre-sowing bio-priming

\begin{tabular}{|c|c|c|c|c|c|c|c|c|}
\hline \multirow[t]{2}{*}{ Varieties } & \multicolumn{4}{|c|}{$\begin{array}{l}\text { Average protein content of seed }(\%) \\
\text { produced }\end{array}$} & \multicolumn{4}{|c|}{$\begin{array}{c}\text { Carbohydrate content of seed } \\
(\%)\end{array}$} \\
\hline & $\mathbf{T}_{\mathbf{0}}$ & $\mathbf{T}_{1}$ & $\mathbf{T}_{2}$ & Mean & $\mathbf{T}_{0}$ & $\mathbf{T}_{1}$ & $\mathbf{T}_{2}$ & Mean \\
\hline Lalu & 14.18 & 14.91 & 14.67 & 14.59 & 7.55 & 7.74 & 7.65 & 7.65 \\
\hline Arka Anamika & 16.45 & 16.94 & 16.75 & 16.71 & 7.65 & 7.90 & 7.83 & 7.80 \\
\hline Ramya & 11.97 & 12.84 & 12.33 & 12.38 & 8.61 & 8.72 & 8.69 & 8.67 \\
\hline Satsira & 9.88 & 11.04 & 11.09 & 10.67 & 7.01 & 7.15 & 7.19 & 7.12 \\
\hline Lady Luck & 15.27 & 15.76 & 15.90 & 15.64 & 5.14 & 5.41 & 5.35 & 5.30 \\
\hline Debpusa Jhar & 13.31 & 13.99 & 13.58 & 13.62 & 7.56 & 7.81 & 7.69 & 7.69 \\
\hline JapaniJhar & 11.92 & 12.93 & 12.64 & 12.50 & 8.44 & 8.57 & 8.54 & 8.52 \\
\hline Barsha Laxmi & 13.22 & 13.51 & 13.56 & 13.43 & 7.67 & 7.89 & 7.83 & 7.80 \\
\hline \multirow[t]{2}{*}{ Mean } & 14.18 & 14.91 & 14.67 & & 7.45 & 7.65 & 7.60 & \\
\hline & V & $\mathbf{T}$ & VXT & & V & $\mathbf{T}$ & VXT & \\
\hline $\operatorname{SEm}( \pm)$ & 0.032 & 0.019 & 0.055 & & 0.028 & 0.016 & 0.046 & \\
\hline CD at $5 \%$ & 0.089 & 0.055 & 0.155 & & 0.080 & 0.045 & NS & \\
\hline
\end{tabular}

$\mathrm{T}_{0^{-}}$Control, $\mathrm{T}_{1^{-}}$Trichoderma viride, $\mathrm{T}_{2}$ - Pseudomonas fluorescens

Significantly lowest magnitude of vigour index was derived for Lady Luck and Debpusa Jhar, may be due to inherited potential of its seedling length as well as greater influence of its seed germination potential (Table 1). Superior influence of Trichoderma viride for determination of average vigour index was observed over Pseudomonas fluorescens. Response of individual varieties towards bio-priming for production of seeds with enhanced vigour over control was significantly noted higher for Arka Anamika (1544.40) followed JapaniJhar, Ramya and Lalu, then treatment was made with Trichoderma viride.

Significant enhancement in germination and seedling parameters of okra and sunflower was recorded by Dawar et al., (2008) through seed treatment with Trichoderma sps. While enhancement in germination potential, vigour index and other seedling parameters can be made possible through seed treatment with both Trichoderma harzianum and Pseudomonas fluorescens by Kimura et al.,
(1992) in cotton and by Entesari et al., (2013) in soybean.

\section{Protein content (\%)}

It could be revealed through Table 2 that average protein content was of significantly highest magnitude for Arka Anamika (16.71\%) followed by Lady Luck, Lalu, Debpusa Jhar and Barsha Laxmi whereas lowest for Satsira (10.68\%). Average influence of Trichoderma viride (14.91\%) was better in enhancement of protein content over both untreated control and bio-priming with Pseudomonas fluorescens (14.67\%).

Response of individual varieties towards bioinoculants for change in protein content of produced seeds was recorded to be varied i.e. greater influence of Trichoderma viride was noticed for Arka Anamika (16.94\%), Lalu (14.91\%), Debpusa Jhar (13.99\%) and Barsa Laxmi (13.51\%) in comparison to that of Pseudomonas fluorescens and it was reverse for Lady Luck (15.90\%). Significant 
improvement in protein content in soybean after application of mycorrhizal fungi including Trichoderma viride was reported by Babiker et al., (1995), Elzidany (1997) and Egberongbe et al., (2010).

\section{Carbohydrate content $(\%)$}

Significant variation among the varieties was noted for its average carbohydrate content. Average influence of both the bio-inoculants was found to be statistically at par, but was positive over control for this character. Highest amount of carbohydrate content was estimated, on an average, from the seeds of Ramya (8.67\%) followed by Japani Jhar, Arka Anamika, Barsha Laxmi, Debpusa Jhar and Lalu, of which that of Barsha Laxmi and Arka Anamika as well as for Debpusa Jhar and Lalu were significantly similar with each.

The same for Lady Luck (5.30\%) was lowest and with very lower magnitude in comparison to that of other varieties, may be due to its inherent potentiality. Bio-priming with both Trichoderma viride $(7.65 \%)$ and Pseudomonas fluorescens (7.60\%) was able to exert significantly superior influence in enhancing carbohydrate content of seeds over control, when average was made over varieties, though insignificantly higher magnitude of this parameter was estimated after bio-priming of seeds with Trichoderma viride in comparison to that with Pseudomonas fluorescens.

Critical analysis for individual varieties also followed the same trend, though interaction effect was insignificant. Observation of Egberongbe et al., (2010) for enhanced carbohydrate content after inoculation with Trichoderma harzianum in soybean may support the enhancement in same for okra after application of Trichoderma viride as recorded in present investigation.
It is concluded in line with these views, in the present study revealed that seed bio-primed with Trichoderma viride was the best treatment for better seed quality.

\section{References}

Abdul-Baki, A.A. and Anderson, J.D. 1973. Vigour determination of soybean seeds by multiple criteria, Crop Sci., 13: 630633.

Babiker, E.E., Elsheikh, E.A.E., Osman, A.G. and Eltinay, A.H. 1995. Effect of nitrogen fixation, nitrogen fertilization and viral infection on yield, tannin and protein contents and in vitro protein digestibility of faba bean. Plant Food Human Nute., 47: 257-263.

Callan, N.W., Mathre, D.E., Miller, J.B. and Vavrina, C.S. 1997. Biological seed treatments: factors involved in efficacy. Horticultural Science 32: 179-183.

Dawar, S., Sattar, A. and Zaki, M.J. 2008. Seed dressing with bio-control agents and nematicides for the control of root knot nematode on sunflower and okra. Pak. J. Bot., 40 (6): 2683-2691.

Egberongbe, H.O., Akintokun, A.K., Babalola, O.O. and Bankole, M.O. 2010.The effect of Glomusmosseae and Trichoderma harzianum on proximate analysis of soybean (Glycine max L. Merrill.) seed grown in sterilized and unsterilised soil. Journal of Agricultural Extension and Rural Development, 2 (4): $54-58$

Elzidany, A.A. 1997. Effect of Rhizobium, organic and chemical fertilizers on proximate composition, in vitro protein digestibility (IVPD), tannin and sulphur content of faba beans. J. Food Chem., 59: 41-45.

Entesari, M., Sharifzadeh, F., Ahmadzadeh, M. and Farhangfar, M. 2013.Seed Biopriming with Trichoderma Species and Pseudomonas fluorescense on 
Growth Parameters, Enzymes Activity and Nutritional Status of Soybean.IJAPP, 4 (4): 610-619.

Harman, G.E., Howell, C.R., Viterbo, A., Chet, I. and Lorito, M. 2004. Trichoderma species-opportunistic, avirulent plant symbionts. Nature Reviews Microbiology 2: 43-56.

Harman, G.E., Petzoldt, R., Comis, A. and Chen, J. 2004. Interactions between Trichoderma harzianum strain t22 and maize inbred line mo17 and effects of these interactions on diseases caused by Pythium ultimum and Colletotrichum graminicola. J. Phytopathol., 94: 147153.

Hedge, J E and Hofreiter, B. T. 1962. In: Carbohydrate Chemistry 17 (Eds Whistler R L and Be Miller, J N) Academic Press New York.

ISTA. 1985. International rules for seed resting. Seed Sci. and Tech., 13 (2): 229-355.

Jain, A., Singh, A., Singh, S. and Singh, H.B. 2013. Microbial consortium-induced changes in oxidative stress markers in pea plants challenged with Sclerotiniasclerotiorum. Journal of Plant Growth Regulation. 32: 388-398.

Kimura, Y., Mizuno, T., Hamasaki, T. and Altochromones, A.B. (1992). New plant growth regulators produced by the fungus Alternaria sp. Biosci. Biotechnol.Biochem.56: 1064-1665.

Lo, C.T. and Lin, C.Y. 200). Screening strains of Trichoderma spp. for plant growth enhancement in Taiwan. Plant pathology Bull., 11: 215-220.

Lo, C.T., Liao, F.T. and Deng, T.C. 2000. Induction of systemic resistance of cucumber to cucumber green mosaic virus by the root colonizing Trichoderma spp. (Abstr.) Phytopathology, 90: S 47.

Lowry, O.H., Rose Brough, J., Farrl, A.L. and Randall, R.J. 1951.Protein measurement with Folin Phenol reagent. Journal of Biological Chemistry, 193:265-275.

Mathivanan, N., Prabhavathy, V.R. and Vijayanandraj, V.R. 2005.Application of Talc Formulations of Pseudomonas fluorescens Migula and Trichoderma viride Pers. ex S.F. Gray Decrease the Sheath Blight Disease and Enhance the Plant Growth and Yield in Rice.J. Phytopathol., 153: 697-701.

Meena, V.K., Dubey, A.K., Jain, V.K, Tiwari, A. and Negi P. 2017. Effect of plant growth promoters on flowering and fruiting attributes of okra [Abelmoschus esculentus (L.) Moench]. Crop Res., 52(1, 2 \& 3): 37-40.

Nayaka, C. S., Niranjana, S.R., Uday Shankar, A.C., Niranjan Raj, S., Reddy, M.S., Prakash, H.S. and Mortensen, C.N. 2010. Seed bio-priming with novel strain of Trichoderma harzianumfor the control of toxigenic Fusarium verticillioides and fumonisins in maize.Archives of Phytopathology and Plant Protection, 43: 264-282.

Pill, W.G., Collins, C.M., Goldberger, B. and Gregory, N. 2009. Responses of nonprimed or primed seeds of 'Marketmore 76'cucumber (Cucumis sativus L.) slurry coated with Trichoderma species to planting in growth media infested with Pythium aphanidermatum. Scientia Horticulturae 121: 54-62.

Rao, M.S.L., Kulkarni, S., Lingaraju, S. and Nadaf, H.L. 2009. Bio-priming of seeds: a potential tool in the integrated management of Alternaria blight of sunflower. HELIA, 32 (50): 107-114.

Reddy, M.T., Haribabu, K., Ganesh, M., Reddy, K.C. and Begum, H. 2012.Genetic divergence analysis of indigenous and exotic collections of okra (Abelmoschus esculentus (L.) Moench). J. of Agr. Tech., 28(2): 611623.

Saxena, M., Bhatacharya, S. and Malhotra, 
S.K. 2016.Horticulture Statistics at a Glance 2015.Ministry of Agriculture \& Farmers Welfare, Government of India, Oxford University Press, New Delhi.

Shanmugaiah, V. 2007.Biocontrol potential of Phenazine -1 - carboxamide producing plant growth promoting rhizobacterium Pseudomonas aeruginosaMML2212 against sheath blight disease of rice. Ph.D. Thesis, University of Madras, Chennai, India.

Shanmugaiah, V., Ramesh, S., Jayaprakashvel, M. and Mathivanan, N. 2005.Biocontrol and plant growth promoting potential of Pseudomonas sp. MML2212 from the rice rhizosphere. In: Proceedings of the 1st Int. Symposium on Biol. Control of Bacterial Plant Diseases, Seeheim/ Darmstadt, Germany, 23rd - 26th October.

Singh, A., Jain, A., Sarma, B.K., Upadhyay, R.S. and Singh, H.B. 2013a.
Rhizosphere microbes facilitate redox homeostasis in Cicerarietinum against biotic stress. Annals of Applied Biology 163: 33-46.

Vinale, F., Sivasithamparam, K., Ghisalberti, E.L., Marra, R., Woo, S.L. and Lorito, M. 2008. Trichoderma-plant-pathogen interactions. Soil Biol. Biochem., 40: 110.

Woo, S.L., Ruocco, M., Vinale, F., Nigro, M., Marra, R., Lombardi, N., Pascale, A., Lanzuise, S., Manganiello, G. and Lorito, M. 2014. Trichoderma-based products and their widespread use in agriculture. The Open Mycology Journal 8

Yedidia, I., Srivastva, A.K., Kapulnik, Y. and Chet, I. 2001. Effect of Trichoderma harzianum on microelement concentrations and increased growth of cucumber plants. Plant and Soil, 235: 235-242.

\section{How to cite this article:}

Anuj Kumar Rai, Himangshu Das and Asit Kumar Basu. 2019. Seed Quality of Okra Produced after Bio-Priming. Int.J.Curr.Microbiol.App.Sci. 8(06): 2166-2173.

doi: https://doi.org/10.20546/ijcmas.2019.806.257 